\title{
MENINGKATKAN KEMAMPUAN PEMECAHAN MASALAH PESERTA DIDIK DENGAN MODEL PEMBELAJARAN PROCESS ORIENTED GUIDED INQUIRY LEARNING (POGIL) MELALUI PENDEKATAN PROBLEM BASED LEARNING (PBL)
}

\author{
Nur Fitri Lestari*, Nanang Supriadi**, Siska Andriani**** \\ Universitas Islam Negeri Raden Intan Lampung \\ nur.fitrilestari0395gmail.com*, nanangsupriadi@gmail.com ${ }^{* *}$, \\ siskaandriani@ radenintan.ac.id ${ }^{* * *}$
}

\begin{abstract}
Abstrak: Pada penelitian ini termasuk penelitian kuantitatif menggunakan jenis eksperimen quasy eksperimen design dan desain pretest-posttest control design. Populasi dalam penelitian ini adalah peserta didik SMP Negeri 5 Natar dan sampel penelitian diambil dengan teknik random sampling sehingga didapatkan sampel penelitian kelas VIII E sebagai kelas eksperimen 1, kelas VIII C sebagai kelas eksperimen 2, dan kelas VIII D sebagai kelas kontrol. Tujuan dari penelitian ini adalah untuk mengetahui adanya pengaruh penerapan Model Pembelajaran Process Oriented Guided Inquiry Learning (POGIL) melalui Pendekatan Problem Based Learning (PBL) terhadap peningkatan kemampuan pemecahan masalah matematis peserta didik. Hasil menunjukkan bahwa kemampuan pemecahan masalah matematis peserta didik pada kelas yang diterapkan Model Pembelajaran Process Oriented Guided Inquiry Learning (POGIL) melalui Pendekatan Problem Based Learning (PBL) lebih baik dari kemampuan pemecahan masalah matematisnya yang diterapkan Model Pembelajaran Process Oriented Guided Inquiry Learning (POGIL) dan Model Pembelajaran Konvensional.
\end{abstract}

Kata Kunci: kemampuan pemecahan masalah; Model Pembelajaran Process Oriented Guided Inquiry Learning (POGIL); Pendekatan Problem Based Learning (PBL).

\section{PENDAHULUAN}

Pendidikan mempunyai peranan penting dalam kehidupan sehari-hari bagi kepentingan pribadi maupun dalam kedudukan sebagai warga negara (Supriadi \& Damayanti, 2016). Pendidikan adalah usaha sadar dan terencana untuk mewujudkan suasana belajar dan proses pembelajaran agar peserta didik secara aktif mengembangkan potensi dirinya untuk memiliki kekuatan spiritual keagamaan, pengendalian diri, kepribadian, kecerdasan, akhlak mulia, serta keterampilan yang diperlukan dirinya, masyarakat, bangsa dan negara (Sukring, 2016). Menurut Hamalik (2015) pendidikan adalah suatu proses dalam rangka mempengaruhi peserta didik supaya mampu menyesuaikan diri sebaik mungkin dengan lingkungannya, dan dengan demikian akan menimbulkan perubahan dalam dirinya yang memungkinkannya untuk berfungsi dalam kehidupan masyarakat.

$$
\text { Pelajaran matematika }
$$
merupakan salah satu mata pelajaran yang sangat penting dalam dunia pendidikan. Pelajaran matematika 
dapat digunakan untuk menyelesaikan persoalan-persoalan di dalam kehidupan sehari-hari (Ratnasari, 2018). Matematika merupakan pelajaran yang terstruktur, terorganisasi, dan berjenjang, artinya antara materi yang satu dengan materi yang lainnya saling berkaitan.

Dalam

pembelajaran

matematika, pemecahan masalah merupakan hal yang sangat penting, bahkan sebagai jantungnya matematika (Widyastuti, 2015). Kemampuan pemecahan masalah merupakan kompetensi dalam kurikulum matematika yang harus dimiliki peserta didik. Melalui kegiatan pemecahan masalah, aspekaspek yang penting dalam pembelajaran matematika dapat dikembangkan dengan baik (Hamidah \& Suherman, 2016). Salah satu tujuan pembelajaran matematika adalah peserta didik dapat menerapkan matematika secara tepat dalam kehidupan sehari-hari serta dalam berbagai ilmu pengetahuan, sehingga hasil belajar peserta didik sesuai dengan yang diharapkan (Kartika, Tastra \& Suwarta, 2014). Namun pada kenyataannya hasil belajar peserta didik dilapangan belum mengembirakan.

Begitu juga yang terjadi di SMP Negeri 5 Natar. Berdasarkan hasil wawancara dengan salah satu guru pengampu mata pelajaran matematika di SMP Negeri 5 Natar dapat diketahui peserta didik masih mengalami kesulitan saat memecahkan suatu masalah. Peserta didik tidak tertarik untuk belajar matematika dan kurang meminati pelajaran matematika, kejenuhan mempelajari materi matematika dianggap terlalu sulit dan menakutkan. Peserta didik sendiri belum mandiri masih mengandalkan materi yang diberikan sekolah dan hanya mendengarkan dan mencatat apa yang diberikan oleh guru, serta peserta didik belum melibatkan kemampuan mereka dalam menyelesaikan suatu masalah.

Hal tersebut mencerminkan kemampuan pemecahan masalah peserta didik yang masih rendah. Berdasarkan hasil pra survey menunjukkan bahwa nilai ulangan tengah semester kelas VIII di SMP Negeri 5 Natar masih rendah. Dari seluruh peserta didik kelas VIII yang memperoleh hasil belajar di atas KKM adalah 24 dari 108 peserta didik, yang artinya hanya $22,2 \%$ peserta didik yang mencapai KKM. Sedangkan yang belum mencapai KKM adalah 84 dari 108 peserta didik, atau sebanyak $77,7 \%$ peserta didik yang belum mencapai KKM. Merujuk dengan hasil pra survey, hasil belajar peserta didik belum sesuai dengan tujuan pembelajaran matematika.

Hasil tersebut diduga karena dipengaruhi oleh banyak faktor penerapan model pembelajaran yang dilakukan di dalam kelas yang belum tepat. Penggunaan metode yang kurang bervariasi yang bisa menyebabkan proses pembelajaran matematika terkesan monoton dan kurang kreatif dan berdampak pada hasil belajar peserta didik. Selain itu yang juga bisa menyebabkan hasil belajar peserta didik menjadi rendah 
adalah kemampuan pemecahan masalah matematis yang dimiliki peserta didik serta pendekatan yang dipilih guru.

Salah satu model pembelajaran yang dapat diterapkan dalam pembelajaran matematika untuk meningkatkan kemampuan pemecahan masalah peserta didik adalah penggunaan Model Pembelajaran Process Oriented Guided Inquiry Learning (POGIL) melalui pendekatan Problem Based Learning (PBL). Model Pembelajaran Process Oriented Guided Inquiry Learning (POGIL) adalah model pembelajaran aktif yang menggunakan belajar dalam tim, aktivitas guided inquiry untuk mengembangkan pengetahuan, pertanyaan untuk meningkatkan kemampuan berpikir kritis dan analitis, memecahkan masalah dan melaporkan, metakognisi, dan tanggung jawab individu (Ningsih, Bambang, \& Sopyan, 2012). Model Pembelajaran Process Oriented Guided Inquiry Learning (POGIL) membimbing peserta didik melalui kegiatan eksplorasi agar peserta didik membangun pemahaman sendiri (inkuiri terbimbing) dengan guru sebagai fasilitator (Farda, Zaenuri, \& Sugiarto, 2017). Sedangkan Pendekatan metode pembelajaran Problem Based Learning (PBL) merupakan pembelajaran berbasis masalah dan peserta didik yang menjadi pusat dalam pembelajaran. Pembelajaran yang di awal selalu disajikan masalah yang menuntut kemampuan berpikir tinggi dan kritis serta penyelesaian masalah.
Berdasarkan beberapa penelitian yang ada, bahwasanya Process oriented Guided Inquiry Learning (POGIL) memberikan efek yang baik bagi peserta didik dibandingkan pembelajaran konvensional. Pembelajaran POGIL dilengkapi dengan LKS dapat meningkatkan prestasi belajar peserta didik. Penelitian lain membuktikan bahwa pembelajaran POGIL dapat meningkatkan prestasi belajar peserta didik secara signifikan.

Kelebihan Model Pembelajaran POGIL di antaranya yaitu dapat membantu peserta didik untuk lebih menemukan sendiri pengetahuannya dan mudah diterapkan pada semua jenjang pendidikan. Selain itu Model Pembelajaran POGIL juga mampu membantu peserta didik dalam meningkatkan keterampilan proses, bertanya, dan mengomunikasikan pengetahuan, serta dapat menjangkau materi pelajaran dalam cakupan yang luas (Malik, 2017).

Peneliti tertarik melakukan penelitian guna meningkatkan kemampuan pemecahan masalah matematis peserta didik dengan menggunakan Model Pembelajaran Process Oriented Guided Inquiry Learning (POGIL) melalui pendekatan Problem Based Learning (PBL).

\section{TINJAUAN TEORETIS}

Model adalah prosedur yang sistematis tentang pola belajar untuk mencapai tujuan belajar serta sebagai pedoman bagi pengajar dalam merencanakan dan melaksanakan aktivitas pembelajaran. Model 
pembelajaran adalah kerangka konseptual/operasional, yang melukiskan prosedur yang sistematis dalam mengorganisasikan pengalaman belajar untuk mencapai tujuan belajar tertentu dan berfungsi sebagai pedoman bagi para pengajar dalam merencanakan dan melaksanakan aktivitas pembelajaran (Hosnan, 2014). Menurut Joice \& Weil, model pembelajaran adalah suatu rencana atau pola yang dapat digunakan untuk membentuk kurikulum (rencana pembelajaran jangka panjang), merancang bahanbahan di pembelajaran dan membimbing pembelajaran di kelas atau yang lain (Rusman, 2013). Model pembelajaran dapat dijadikan pola pilihan, artinya para guru boleh memilih model pembelajaran yang sesuai dan efisien untuk mencapai tujuan pendidikannya.

\section{Model Pembelajaran Process Oriented Guided Inquiry Learning (POGIL)}

\section{Process Oriented Guided}

Inquiry Learning (POGIL) diartikan sebagai pembelajaran dengan proses interaktif tentang berfikir secara hatihati, mendiskusikan ide, mencerahkan pemahaman, melatih kemampuan, mencerminkan kemajuan, dan mengevaluasinya (Farda, Zaenuri, and Sugiarto, 2017). Process Oriented Guided Inquiry Learning (POGIL) merupakan model pembelajaran dalam ruang kelas atau laboratorium yang mengajarkan materi/bahan ajar secara simultan dan menekankan pendekatan proses yaitu kemampuan berpikir analitis dan bekerja secara efektif sebagai bagian kolaborasi dalam kelompok (Fujiati, 2014).

Kegiatan pembelajaran Process Oriented Guided Inquiry Learning (POGIL), guru hanya berperan sebagai leader (pemimpin), asesor, fasilitator, dan evaluator sedangkan peserta didik aktif mengkonstruk pengetahuan secara berkelompok. Model pembelajaran ini membimbing peserta didik melalui kegiatan eksplorasi agar peserta didik membangun pemahaman sendiri (inkuiri terbimbing) dengan guru sebagai fasilitator. Tahapan atau fase pembelajaran Process Oriented Guided Inquiry Learning (POGIL) adalah orientasi (orientation), eksplorasi (exploration), penemuan konsep atau pembentukan konsep (concept invention or concept formation), aplikasi (application) dan penutup (closure).

\section{Pendekatan Problem Based Learning (PBL)}

Problem Based Learning (PBL) adalah suatu pendekatan, yang mana sejak awal dihadapkan pada suatu masalah yang kemudian diikuti proses pencarian informasi yang bersifat student centered (Suprihatiningrum, 2013). Pembelajaran berdasarkan masalah merupakan pendekatan yang efektif untuk pembelajaran proses berpikir tingkat tinggi. Pendekatan pengajaran adalah suatu jalan yang ditempuh oleh pengajar dalam mencapai tujuan pengajaran di tinjau dari sudut bagaimana materi itu disusun dan disajikan. Pendekatan PBL 
merupakan pendekatan pembelajaran yang di awal menyajikan permasalahan terstruktur dengan baik yang harus dipecahkan pada akhir pembelajaran, sehingga dapat melakukan penyelidikan untuk memperoleh pengetahuan saat pembelajaran (Suprihatiningrum, 2013).

Pendekatan PBL diakui sebagai
suatu pengembangan dari
pembelajaran aktif dan pendekatan pembelajaran yang berpusat pada peserta didik, yang menggunakan masalah yang terstruktur, masalah yang disajikan dekat dengan kehidupan dunia nyata atau masalah simulasi yang kompleks sebagai titik awal dalam pembelajaran. Menjadikan pembelajaran menjadi aktif dan menyenangkan, sehingga membuat peserta didik memiliki kemampuan pemecahan masalah yang tinggi.

Pembelajaran berdasarkan masalah atau lebih dikenal dengan Problem Based Learning (PBL) merupakan model pembelajaran yang dirancang bertujuan untuk :

1) Mengembangkan keterampilan berpikir, pemecahan masalah, dan intelektual.

2) Mengembangkan keterampilanketerampilan yang kreatif dengan pembelajaran secara mandiri.

3) Belajar peran dalam situasi dunia nyata.

\section{METODOLOGI PENELITIAN}

\begin{tabular}{lcr}
\multicolumn{1}{c}{ Jenis } & penelitian & yang \\
digunakan & adalah & Quasi \\
Experimentasi & Design. & Jenis \\
eksperimen & tersebut & adalah
\end{tabular}

eksperimen yang mempunyai kelompok kontrol, tetapi tidak mengontrol sepenuhnya faktor luar yang dapat berpengaruh terhadap pelaksanaan dalam kelompok eksperimen (Sugiyono, 2013). Penelitian dijalankan dengan Pretest Posttest Control Grup Design (Arikunto, Safruddin, \& Jabar, 2014). Model Pembelajaran POGIL melalui pendekatan PBL merupakan variabel bebas (Independent Variable), sedangkan kemampuan pemecahan masalah matematis peserta didik merupakan variabel terikat (dependent variable) Penelitian ini melibatkan tiga kelas yakni kelas eksperimen 1 yang pembelajarannya menggunakan Model Pembelajaran Process Oriented Guided Inquiry Learning (POGIL), kelas eksperimen 2 process oriented guided inquiry learning (POGIL) melalui pendekatan problem based learning (PBL) dan kelas kontrol yang menggunakan pembelajaran konvensional.

Populasi dalam penelitian ini adalah seluruh peserta didik kelas VIII semester I SMP Negeri 5 Natar tahun pelajaran 2018/2019 yaitu peserta didik kelas VIIIA, VIIIB, VIIIC, VIII D, dan VIIIE. Pengambilan sampel dalam penelitian ini dilakukan dengan teknik simple random sampling. Teknik pengumpulan data yang dilakukan melalui tes berupa soal uraian (essay). Untuk uji coba instrumen, peneliti menggunakan uji validitas, uji reliabilitas, uji tingkat kesukaran, dan uji daya pembeda soal. 
Untuk analisis datanya di dalam penelitian ini peneliti menggunakan teknik sebagai berikut:

1. Uji normalitas, uji ini dilakukan guna mengetahui sampel yang diteliti memiliki distribusi yang normal atau tidak. Uji kenormalan yang digunakan peneliti adalah uji lilliefors.

2. Uji homogenitas, uji homogenitas dilakukan bertujuan untuk mengetahui populasi yang ada pada penelitian mempunyai variansi sama atau tidak. Peneliti menggunakan uji Bartlet untuk menguji homogenitas data.

3. Uji hipotesis, Uji hipotesis yang dilakukan pada penelitian ini menggunakan teknik analisis data Analisis Varians satu arah. Tujuan dari uji anova satu jalan yaitu untuk mengetahui dampak yang disebabkan oleh variabel bebas terhadap variabel terikat dengan membandingkan rerataan beberapa populasi.

4. Uji Lanjut (uji komparasi ganda), setelah data selesai dianalisis dengan anova satu jalan

selanjutnya dilakukanlah uji komparasi ganda sebagai tindak lanjut untuk mengetahui adanya perbedaan rerataan pada setiap pasangan baris, kolom, dan sel. Uji komparasi ganda atau uji lanjut yang dilakukan peneliti pada penelitian ini dengan menggunakan uji Scheffe (Budiono, 2011).

\section{HASIL DAN PEMBAHASAN}

Dari seluruh rangkaian penelitian yang telah dilakukan, maka diperoleh hasil penelitian ini yaitu terdapat pengaruh penerapan Model Pembelajaran Process Oriented Guided Inquiry Learning (POGIL) melalui Pendekatan Problem Based Learning (PBL) terhadap peningkatan kemampuan pemecahan masalah matematis peserta didik. Di awal pembelajaran peneliti memberikan (pretest) untuk mengetahui kemampuan awal peserta didik.

Tabel 1

Rangkuman Uji Anova Data Hasil Posttest Kemampuan Pemecahan Masalah

\begin{tabular}{llllll}
\hline & $\begin{array}{l}\text { Sum of } \\
\text { Squares }\end{array}$ & Df & Mean Square & F & Sig. \\
\hline Between Groups & 3111,547 & 2 & 1555,773 & 7,102 & 0,002 \\
\hline Within Groups & 15773,120 & 72 & 219,071 & & \\
\hline Total & 18884,667 & 74 & & & \\
\hline
\end{tabular}

Berdasarkan hasil analisis uji anova yang terdapat pada Tabel 1 diperoleh nilai signifikansi 0,002 . Nilai signifikansi $0,002<0,05$ maka $H_{0}$ ditolak dan $H_{1}$ diterima artinya hal ini menunjukkan bahwa pembelajaran yang menggunakan Model

Pembelajaran Process Oriented Guided Inquiry Learning (POGIL) melalui pendekatan Problem Based Learning (PBL), menggunakan Model Pembelajaran Process 
Oriented Guided Inquiry Learning (POGIL) dan menggunakan pembelajaran konvensional memberikan pengaruh yang berbeda terhadap peningkatan kemampuan pemecahan masalah matematis peserta didik.
Untuk mengetahui nilai peningkatan kemampuan pemecahan masalah setelah dan sebelum melaksanakan proses pembelajaran, maka dilakukan uji $N$-Gain.

Tabel 2

Rangkuman Skor Pretest, Posttest, dan N-Gain Kemampuan Pemecahan

\begin{tabular}{lllll}
\multicolumn{5}{c}{ Masalah } \\
\hline Kelas & Pretest & Posttest & N-Gain & Interpretasi \\
\hline Eksperimen 1 & 30,120 & 60,440 & 0,367 & Sedang \\
\hline Eksperimen 2 & 37,920 & 60,800 & 0,382 & Sedang \\
\hline Kontrol & 30,120 & 46,960 & 0,227 & Rendah \\
\hline
\end{tabular}

Nilai rata-rata $\mathrm{N}$-Gain terdapat pada kelas eksperimen 1 dengan nilai sebesar 0,367 termasuk kategori sedang. Nilai rata-rata $\mathrm{N}$-Gain terdapat pada kelas eksperimen 2 dengan nilai sebesar 0,382 termasuk kategori sedang.Sedangkan Nilai ratarata $N$-Gain terdapat pada kelas kontrol dengan nilai sebesar 0,227 termasuk kategori rendah. Dapat disimpulkan bahwa rata-rata kemampuan pemecahan masalah peserta didik melalui pembelajaran POGIL melalui pendekatan PBL lebih baik dari Model Pembelajaran konvensional.

Setelah dalam keputusan uji $\mathrm{H}_{0}$ ditolak, maka selanjutnya dilakukan uji lanjut dengan uji Scheffe. Uji Scheffe digunakan dalam penelitian ini guna mengetahui pengaruh model mana yang lebih baik terhadap peningkatan kemampuan pemecahan masalah matematis peserta didik. Hasil output uji lanjut Scheffe dengan menggunakan SPSS adalah sebagai berikut:

\section{Tabel 3}

\section{Rangkuman Uji Scheffe Data $N$-Gain Kemampuan Pemecahan Masalah}

\begin{tabular}{|c|c|c|c|c|c|c|}
\hline \multirow{2}{*}{$\begin{array}{l}\text { (I) } \\
\text { Kelas }\end{array}$} & \multirow{2}{*}{$\begin{array}{l}(\mathrm{J}) \\
\text { Kelas }\end{array}$} & \multirow{2}{*}{$\begin{array}{l}\text { Mean Difference } \\
(\mathrm{I}-\mathrm{J})\end{array}$} & \multirow[b]{2}{*}{$F_{\text {tabel }}$} & \multirow[b]{2}{*}{ Sig. } & \multicolumn{2}{|c|}{$95 \%$ Confidence Interval } \\
\hline & & & & & $\begin{array}{l}\text { Lower } \\
\text { Bound }\end{array}$ & Upper Bound \\
\hline 2 & 1 & 0,155 & 0,060 & 0,042 & -0.004 & 0.306 \\
\hline 2 & 3 & 0,145 & 0,060 & 0,971 & -0.136 & 0,165 \\
\hline 1 & 3 & 0,140 & 0,060 & 0,072 & -0.291 & 0.010 \\
\hline
\end{tabular}

Berdasarkan tabel di atas diketahui bahwa komparansi $F_{\mu_{2}-\mu_{1}}$ memiliki besar $F_{i-j}=0,155$ di mana lebih besar dari $F_{\text {tabel }}$ maka $\mathrm{H}_{0}$ ditolak, sedangkan pada komparansi $F_{\mu_{2}-\mu_{3}}$ besar $F_{i-j}=0,145$ di mana lebih besar dari $F_{\text {tabel }}$ maka $\mathrm{H}_{0}$ 
ditolak, dan pada komparansi $F_{\mu_{1}-\mu_{3}}$ besar $F_{i-j}=0,140$ di mana lebih besar dari $F_{\text {tabel }}$ maka $\mathrm{H}_{0}$ ditolak. Berdasarkan hasil uji Scheffe data $n$ gain kemampuan pemecahan masalah didapatkan kesimpulan:

a. Pada $\mathrm{H}_{0}: \mu_{2}=\mu_{1}$ ditolak, berarti ratarata peningkatan kemampuan pemecahan masalah peserta didik yang diajarkan dengan Model Pembelajaran POGIL tidak sama dengan rata-rata peningkatan kemampuan pemecahan masalah peserta didik yang diajarkan dengan Model Pembelajaran POGIL melalui pendekatan PBL Pada Tabel 2 dapat dilihat bahwa rata-rata n-gain kemampuan pemecahan masalah peserta didik yang diajarkan dengan Model Pembelajaran POGIL melalui pendekatan PBL sebesar 0,382 lebih besar dibandingkan Rata-rata $n$-gain kemampuan pemecahan masalah peserta didik yang diajarkan dengan Model Pembelajaran POGIL sebesar 0,367 .

b. Pada $\mathrm{H}_{0}: \mu_{2}=\mu_{3}$ ditolak, berarti ratarata peningkatan kemampuan pemecahan masalah peserta didik yang diajarkan dengan Model Pembelajaran POGIL melalui pendekatan PBL tidak sama dengan rata-rata peningkatan kemampuan pemecahan masalah peserta didik yang diajarkan dengan Model Pembelajaran Konvensional. Pada Tabel 2 dapat dilihat bahwa rata-rata n-gain kemampuan pemecahan masalah peserta didik yang diajarkan dengan Model Pembelajaran
POGIL melalui pendekatan PBL sebesar 0,382 lebih besar dibandingkan rata-rata n-gain kemampuan pemecahan masalah peserta didik yang diajarkan dengan Model Pembelajaran Konvensional sebesar 0,227.

c. Pada $\mathrm{H}_{0}: \mu_{1}=\mu_{3}$ ditolak, berarti ratarata peningkatan kemampuan pemecahan masalah peserta didik yang diajarkan dengan Model Pembelajaran POGIL tidak sama dengan rata-rata peningkatan kemampuan pemecahan masalah peserta didik yang diajarkan dengan Model Pembelajaran Konvensional. Pada tabel 2 dapat dilihat bahwa rata-rata n-gain kemampuan pemecahan masalah peserta didik yang diajarkan dengan Model Pembelajaran POGIL sebesar 0,367 lebih besar dibandingkan rata-rata n-gain kemampuan pemecahan masalah peserta didik yang diajarkan dengan Model Pembelajaran Konvensional sebesar 0,227.

Berdasarkan tabel di atas dapat dikatakan bahwa model pembelajaran 2 yaitu Model Pembelajaran Process Oriented Guided Inquiry Learning (POGIL) melalui Pendekatan Problem Based Learning (PBL) memberikan pengaruh yang paling baik terhadap peningkatan kemampuan pemecahan masalah matematis peserta didik dibandingkan kedua pembelajaran yang lain.

\section{SIMPULAN DAN SARAN}

Dari seluruh rangkaian penelitian yang telah dilakukan, mulai dari tahap perencanaan, pelaksanaan, 
hingga pada tahap analisis data dan uji hipotesis maka dapat peneliti simpulkan bahwa: Terdapat pengaruh penerapan Model Pembelajaran Process Oriented Guided Inquiry Learning (POGIL), Model Pembelajaran Process Oriented Guided Inquiry Learning (POGIL) melalui Pendekatan Problem Based Learning (PBL), dan Model Pembelajaran Konvensional terhadap peningkatan kemampuan pemecahan masalah matematis peserta didik kelas VIII SMP Negeri 5 Natar. Kemampuan pemecahan masalah matematis mendapatkan hasil yang paling baik pada kelas yang diterapkan Model Pembelajaran Process Oriented Guided Inquiry Learning (POGIL) melalui Pendekatan Problem Based Learning (PBL) dibandingkan dua kelas pembelajaran lainnya.

Berdasarkan hasil penelitian yang telah dilaksanakan oleh peneliti, disarankan kepada guru bidang study matematika untuk dapat menggunakan Model Pembelajaran Process Oriented Guided Inquiry Learning (POGIL) melalui Pendekatan Problem Based Learning (PBL), agar pemecahan masalah matematis peserta didik bisa meningkat dari sebelumnya. Penelitian ini masih terbatas pada kemampuan pemecahan masalah matematis peserta didik, diharapkan pada rekan peneliti untuk dapat melakukan penelitian lanjutan dalam ruang lingkup yang lebih.

\section{DAFTAR PUSTAKA}

Arikunto, S., Safruddin, C., \& Jabar,
A. (2014). Evaluasi Program Pendidikan. Jakarta: Bumi Aksara.

Budiyono.(2009). Statistika Untuk Penelitian. Surakarta: UNS Pers.

Farda, H., Zaenuri, Z., \& Sugiarto, S. (2017). Effectiveness of POGIL Learning Model with Ethnomathematics Nuance Assisted by Student Worksheet Toward Student Mathematical Communication Skill. Journal of Mathematics Education Unnes, Vol.6(No.2), p.225.

Hamalik, O. (2015). Kurikulum Dan Pembelajaran (Cet.ke-15, p. p.3). Jakarta: PT. Bumi Aksara.

Hamidah, K., \& Suherman. (2016). Proses Berpikir Matematis Siswa Dalam Menyelesaikan Masalah Matematika Di Tinjau Dari Tipe Kepribadian Keirsey. Al-Jabar: Jurnal Pendidikan Matematika, Vol.7(No.2), p.231-248.

Malik, A., Viani, O., \& Wahyuni Handayani, M. M. C. (2017). Penerapan Model Process Oriented Guided Inquiry Learning (POGIL) Untuk meningkatkan Keterampilan Berpikir Kritis Peserta Didik.

Ningsih, S. M., Bambang, S., \& Sopyan, A. (2012). Implementasi Model Pembelajaran Process Oriented Guided Inquiry Learning (POGIL) Untuk Meningkatkan Kemampuan Berpikir Kritis Siswa. UPEJ Unnes Physics Education Journal, Vol.1(No.2), p.46. 
Ratnasari, N. (2018). Project Based Learning (PjBL) Model on the Mathematical Representation Ability. Tadris: Jurnal Keguruan Dan Ilmu Tarbiyah, Vol.3(No.1), p.47-53.

Sukring. "Pendidik Dalam Pengembangan Kecerdasan Peserta Didik (Analisis Perspektif Pendidikan Islam)." Tadris: Jurnal Keguruan Dan Ilmu Tarbiyah 1, no. 1 (June 17, 2016): 5768.

Supriadi, Nanang, and Rani Damayanti, "Analisis Kemampuan Komunikasi Matematis Siswa Lamban Belajar dalam Menyelesaikan Soal Bangun Datar," $A l$ -
Jabar: Jurnal Pendidikan Matematika 7, no. 1 (June 16, 2016): 1-9.

Sugiyono. (2013). Metode Penelitian Pendidikan (Pendekatan Kuantitatif, Kualitatif, dan $R$ \& D). Bandung: Alfabeta.

Suprihatiningrum, J. (2015). Strategi Pembelajaran Teori \& Aplikasi. Yogyakarta: ArRuzz Media Publisher.

Widyastuti, R. (2015). Proses Berpikir Siswa Dalam Menyelesaikan Masalah Matematika Berdasarkan Teori Polya Ditinjau Dari Adversity Quotient Tipe Climber. Al-Jabar: Jurnal Pendidikan Matematika, Vol.6(No.2), p.183-194. 